\title{
Evaluation of wood properties from six native species of forest plantations in Costa Rica
}

\author{
Estudio de propiedades de la madera de seis especies nativas en plantaciones de Costa Rica
}

\author{
Carolina Tenorio a, Róger Moya ${ }^{\text {a*, }}$, Cynthia Salas a, Alexander Berrocal a \\ * Corresponding author: ${ }^{a}$ Instituto Tecnológico de Costa Rica, Escuela de Ingeniería Forestal, \\ Apartado 159-7050, CIIBI-ITCR, Cartago, Costa Rica, rmoya@itcr.ac.cr
}

\begin{abstract}
SUMMARY
This study details information about physical, chemical and mechanical properties, drying, preservation and workability of wood from Cordia alliodora, Dipteryx panamensis, Enterolobium cyclocarpum, Hieronyma alchorneoides, Samanea saman and Vochysia ferruginea trees, growing in forest plantations in Costa Rica. Variation of the general properties in relation to height showed that heartwood percentage decreases, bark percentage increases and pith percentage is not affected. Dipteryx panamensis showed both the highest values for specific gravity and the highest mechanic resistance. Both chemical properties and extractives presence were different among species. Heartwood was not possible to preserve in any of the species, though sapwood was. Penetration varied from partial irregular or vascular in the species. The highest durability was for Hieronyma alchorneoides and Vochysia ferruginea, species classified as of high durability. Finally, all species had good performance in the workability tests. The previous results indicate that these species, used for trading reforestation in Costa Rica, have acceptable characteristics to be commercialized and used in wooden products.
\end{abstract}

Key words: tropical species, Central America, wood variation, commercial wood.

\section{RESUMEN}

El presente estudio detalla información de las propiedades físicas, químicas, mecánicas, de secado, preservación y trabajabilidad de la madera de Cordia alliodora, Dipteryx panamensis, Enterolobium cyclocarpum, Hieronyma alchorneoides, Samanea saman y Vochysia ferruginea proveniente de plantaciones forestales en Costa Rica. La variación de las propiedades con respecto a la altura mostró que el porcentaje de duramen disminuyó, el porcentaje de corteza aumentó y el porcentaje de médula no se vio afectado por la altura del árbol. Dipteryx panamensis presentó los valores de peso específico más altos, por lo tanto, también presentó los valores de resistencia mecánica más altos. No fue posible preservar el duramen en ninguna especie, pero la albura sí y su penetración varió de parcial irregular o vascular en las especies. La mayor durabilidad se presentó en Hieronyma alchorneoides y Vochysia ferruginea, especies clasificadas como de alta durabilidad. Finalmente, todas las especies presentaron buen comportamiento en las pruebas de trabajabilidad. Los resultados anteriores indican que estas especies, utilizadas en la reforestación comercial de Costa Rica, poseen características aceptables para ser utilizadas en la comercialización y uso en productos de madera.

Palabras clave: especies tropicales, América Central, variación de madera, maderas comerciales.

\section{INTRODUCTION}

Costa Rica, as other Central America countries, has an enormous variety of possibilities to establish plantations with native or exotic species (Moya et al. 2009). Some of them have become important for commercial reforestation (Nichols and Vanclay 2012).

Nowadays it is possible to find studies on native species performance in commercial reforestation in fast-growing plantations (Nichols and Vanclay 2012). The reforestation with native species are characterized by a promising productivity, good development in degraded areas, nutritional benefits in soil fertility, possibility of developing agroforestry and silvopastoral systems, fixation and carbon sequestration, among others (Montagnini 2000).
Likewise, a significant number of investigations had studied aspects related to physical, chemical, mechanical and energetic properties (Moya and Muñoz 2010, Tenorio and Moya 2013, Moya and Tenorio 2013) of wood performance during the drying (Tenorio and Moya 2011, Moya et al. 2013) and preservation processes and about durability and workability (Moya et al. 2009, 2015) of native species from Costa Rica used in commercial plantations.

Native species such as Cordia alliodora (Ruiz et Pav) Okan (Fam: Boraginaceae), Dipteryx panamensis (Pittier) Record et Mell (Fam: Fabaceae), Enterolobium cyclocarpum (Jacq.) Griseb (Fam: Fabaceae), Hieronyma alchorneoides Allemao (Fam: Phyllantaceae), Samanea saman (Jacq.) Merrill (Fam: Fabaceae) and Vochysia ferruginea Mart (Fam: Vochysiaceae) have gained popularity in di- 
fferent reforestation projects in Costa Rica (C Moya et al. 2009), in spite of the lack of information concerning wood properties, which becomes a limitation in their use (Moya et al. 2015).

For some of these species it is possible to find specific studies with very limited information about their wood properties. For example, Butterfield et al. (1993) conducted a study on basic density variation in radial direction, fiber length and vessels area in wood from plantation trees of H. alchorneoides. Recently, Obando and Moya (2013) studied density, specific gravity, shrinkage and color of wood from 19 years-old trees of S. saman and E. cyclocarpum from mixed plantations. For the other species, studies available focus on silvicultural performance, indicating that relevant information is still lacking; specifically about their different properties and performance and quality during sawing, their drying process, preservation, durability and workability. All important to determine possible uses that can be given to certain native species from plantations.

Whereas in Costa Rica a new group of native species used in commercial fast-growing plantations is emerging as alternative wood and therefore, the knowledge of different wood properties, their variation and differences among species appears as necessary. The present work aims at determining physical, chemical and mechanical properties, drying, preservation and workability characteristics of wood from Cordia alliodora (Ruiz et Pav) Okan, Dipteryx panamensis (Pittier) Record et Mell, Enterolobium cyclocarpum (Jacq.) Griseb, Hieronyma alchorneoides Allemao, Samanea saman (Jacq.) Merrill and Vochysia ferruginea Mart. from forest plantation, and applying this information as a guide for different uses.

\section{METHODS}

Plantation description and tree sampling. Six native species were studied: C. alliodora, D. panamensis, E. cyclocarpum, H. alchorneoides, S. saman and V. ferruginea (table 1). Nine trees per species were randomly selected for harvesting, including suppressed, intermediate and dominant trees, in accordance with the methodology deve- loped by Moya and Muñoz (2010). Selected trees, with straight trunks, normal branching and no disease or pest symptoms, were felled.

Two stem sections from the base to $2.5 \mathrm{~m}$ high were obtained from each tree (with $1.25 \mathrm{~m}$ in length) (figure 1A). Among these logs, a cross-sectional sample of $3.0 \mathrm{~cm}$ wide was taken at basal part and at $1.3 \mathrm{~m}$ in height, the diameter at breast height (DBH). Afterwards, stem discs were cut at $25 \%, 50 \%, 75 \%$ and $100 \%$ of commercial height (figure 1A). Stem log with 2.5 m-length were cut from $25-50 \%$, from $50-75 \%$ and $75-100 \%$ of commercial height. The North-South direction was marked on each stem crosssection and logged for later identification in the laboratory.

Heartwood, pith, and bark percentage determination. Total diameter, diameter without bark, pith diameter, and heartwood diameter (figure 1B), when different, were measured on a cross-sectional line drawn in two directions (north-south and east-west). Means for all diameters were calculated as the average of two cross-sectional measurements on each stem section. Total heartwood and pith cross-sectional area were calculated as a geometric circle and bark content was determined through the difference between total area and area without bark.

Physical and mechanical properties. A $3.0 \mathrm{~cm}$ wide block was cut along the center (including the pith) of each disk of different height and divided into two sub samples (cut in half) for studying the physical wood properties (figure 1C). Specific gravity was determined using both sub samples. The volume of each sample was defined as the volume of water displaced when submerged, according to ASTM D2395-14 standards (ASTM 2014a). Wood density was calculated as green mass divided by green volume and it was renamed green density while the specific gravity was calculated as oven-dry weight $\left(105^{\circ} \mathrm{C}, 48\right.$ hours $)$ divided by green volume (figure 1C-D).

Furthermore, total volumetric shrinkage was determined in the same samples through dimension difference between green and anhydrous condition $(0 \%)$. To determine total shrinkage (from green to oven-dried) tangentially and

Table 1. Dasometric parameters and age of the species sampled.

Parámetros dasométricos y edad de las plantaciones muestreas.

\begin{tabular}{lccccc}
\hline \multicolumn{1}{c}{ Species } & $\begin{array}{c}\text { Age } \\
(\text { years })\end{array}$ & $\begin{array}{c}\text { Density } \\
\left(\text { trees ha }{ }^{-1}\right)\end{array}$ & $\begin{array}{c}\text { Total height } \\
(\mathrm{m})\end{array}$ & $\begin{array}{c}\text { Diameter breast } \\
\text { height }(\mathrm{cm})\end{array}$ & $\begin{array}{c}\text { Heartwood at diameter } \\
\text { breast height }(\%)\end{array}$ \\
\hline Cordia alliodora & 14 & 439 & 14.6 & 14.0 & 23.4 \\
Dipteryx panamensis & 13 & 458 & 20.4 & 15.6 & 24.8 \\
Enterolobium cyclocarpum & 20 & 122 & 14.8 & 35.4 & 33.1 \\
Hieronyma alchorneoides & 12 & 332 & 24.8 & 22.8 & 10.3 \\
Samanea saman & 20 & 148 & 16.3 & 32.9 & 52.5 \\
Vochysia ferruginea & 8 & 309 & 16.9 & 25.3 & 25.0 \\
\hline
\end{tabular}



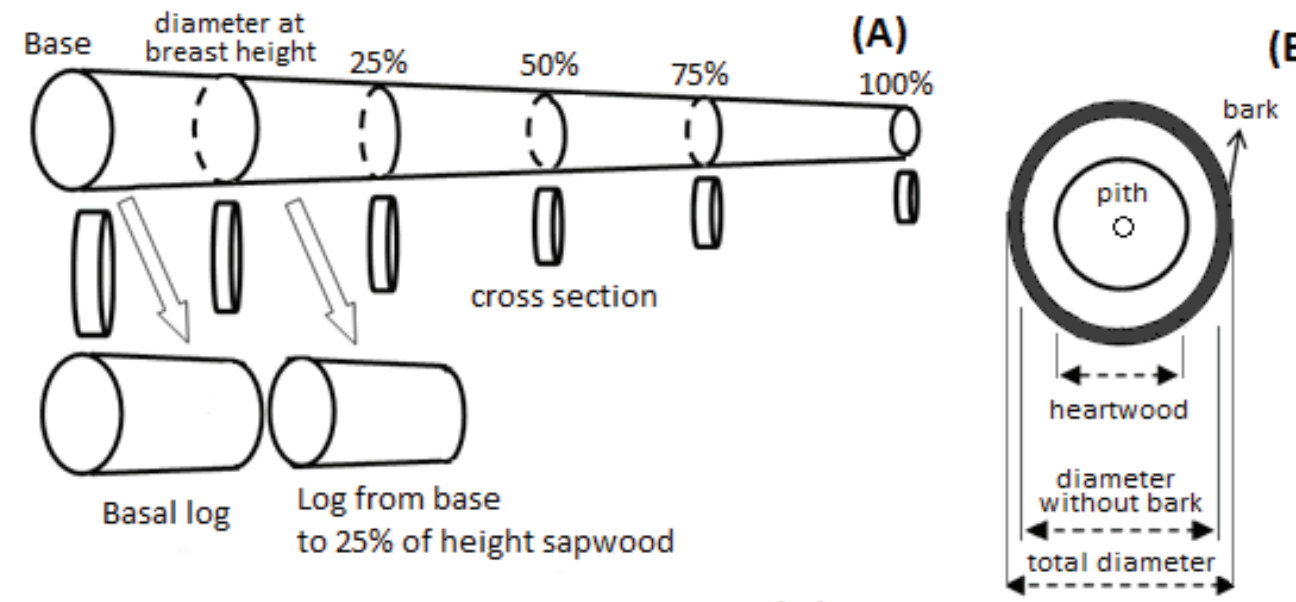

(B)

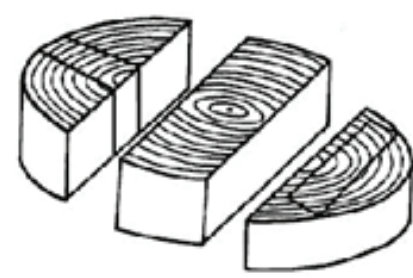

(C)

(D)

(E)
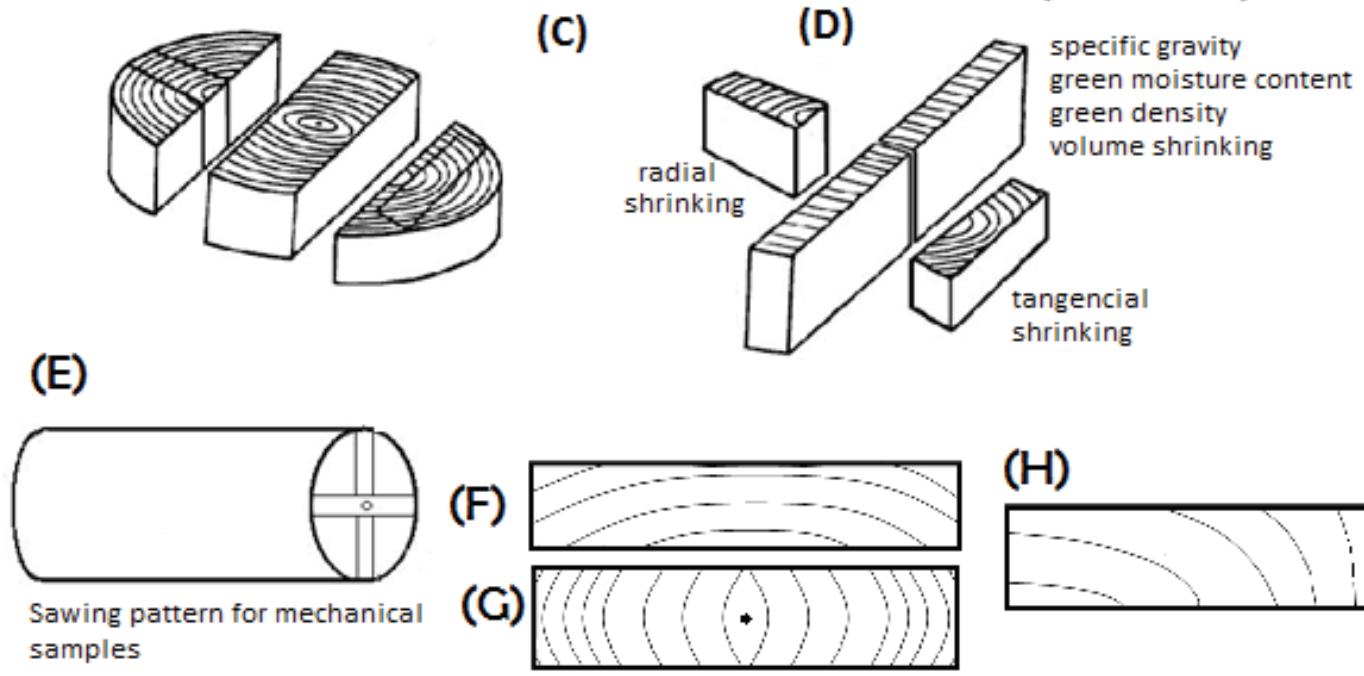

(H)

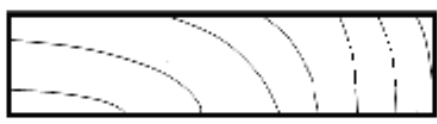

Figure 1. Sampled trees (A), diametrical measures (B), sampling for physical properties determination and shrinking (C-D), sawing pattern used for mechanical properties determination $(\mathrm{E})$, tangential grain $(\mathrm{F})$, radial grain $(\mathrm{G})$ and oblique grain $(\mathrm{H})$.

Muestreo de árboles (A), mediciones diamétricas (B), muestreo para la determinación de las propiedades físicas y contracciones (C-D) y patrón de corte para la determinación de las propiedades mecánicas $(\mathrm{E})$, patrón tangencial $(\mathrm{F})$, patrón radial $(\mathrm{G})$ y patrón oblicuo $(\mathrm{H})$.

radially, two samples were cut from the pieces left from the disc at DBH.

The logs taken from the base of the tree to DBH (figure $1 \mathrm{E})$ were used for determining the static bending (modulus of rupture and modulus of elasticity), compression parallel to grain (maximum crushing stress), shear parallel to grain (maximum shearing stress) and side Janka hardness. A total of 18 samples per species were prepared per each test, following ASTM D143-14 standards (ASTM 2014b).

Determination of chemical properties and extractives in different solvents. From cross - section at DBH in each trees and species, wood samples were milled $30 \mathrm{~g}$ to a particle size of less than $0.6 \mathrm{~mm}$ and then screened through a 40 and a 60 mesh for chemical analyses, extractives content and inorganic ash compositions analyses. Particles screened from three trees were grouped, and subsequently three groups from nine trees were obtained. Three sam- ples from each group were used for ash, lignin and holocellulose content, $\mathrm{pH}$ measured, silica and different extractives. Ash content determination was done through the D1102-84 standard (ASTM 2013a); to quantify lignin the T222 om-02 method was used (TAPPI 2002) and for holocellulose determination Erickson's methods (1962) were followed. Twelve aqueous solutions of $1 \mathrm{~g}$ sawdust in 5 $\mathrm{ml}$ of water were used for measuring the $\mathrm{pH}$ of the tissues, using an Accumet AP61 pH meter. Extractives content was determined in water (hot and cool condition) (ASTM 2013b), in sodium hydroxide ( $\mathrm{NaOH}$ ) (ASTM 2013c), in an ethanol-toluene solution (ASTM 2013d) and in dichloromethane $\left(\mathrm{CH}_{2}-\mathrm{Cl}_{2}\right)$ (ASTM 2013e). For the inorganic ash compositions analysis, the method of Sparks (1996) was used, and included determination of mass of nitrogen, phosphorus, calcium, magnesium, potassium and sulfur, whose concentrations were reported as percentages; and iron $(\mathrm{Fe})$, manganese $(\mathrm{Mn})$, copper $(\mathrm{Cu})$, zinc $(\mathrm{Zn})$ and bo- 
ron (B), whose concentrations were reported as milligrams of inorganic element per kilogram of ash.

Preservation and decay resistance. In the preservation performance, the vacuum-pressure method was applied. A total of nine log samples per specie, with $30 \mathrm{~cm}$ - length, cut after commercial height, were treated with Wolmanit CX$10 \mathrm{O}$ preservatives (Bis-(N-cyclohexyldiazniumdioxy)copper) (3.5\%), copper hydroxide carbonate $(16.3 \%)$, boric acid $(5.0 \%)$ and 2 -aminoethanol $(25-45 \%)$ at $2.8 \%$ $\mathrm{v} / \mathrm{v}$ concentration. All samples were placed into an experimental preservation tank under a pressure of $690 \mathrm{kPa}$ (approximately $100 \mathrm{psi}$ ). The preservation process consisted of 30 minutes of vacuum, 2 hours of pressure and 15 minutes of vacuum. The samples were weighed before and after the preservation process; for pressure preservation, the absorption capacity was calculated as the absorption of preservatives (liters) by timber volume $\left(\mathrm{m}^{3}\right)$, while preservative retention was determined considering the absorption per species given by the difference in weight and concentration of preservative solution.

Decay resistance was determined for non-treated sapwood and heartwood samples and treated sapwood and heartwood with preservatives. Thirty samples of $20 \times 20$ $\times 20 \mathrm{~mm}$ size from the each type of tissue at breast height diameter and other 60 samples of $20 \times 20 \times 20 \mathrm{~mm}$ size from treated sapwood and heartwood from preservatives were extracted. Two white-rot fungi, Trametes versicolor L. Fr. and Pycnoporus sanguineus (L.) Murrill, were used for the natural durability test under laboratory conditions (accelerated test) following D2017-81 procedures (ASTM 2005). The relative resistance of each test block to decay was measured as the loss percentage of oven dry weight during a 12 - week exposure.

Workability. Boards of $2.5 \mathrm{~cm}$ thick, previously oven dried to a moisture content of $12 \%$ on the study developed by Tenorio et al. (2015), were used. From the drying bath, 30 boards were selected considering three types of grain patterns (10 samples of tangential grain-figure $1 \mathrm{~F}, 10$ samples of radial grain- (figure $1 \mathrm{G}$ and 10 oblique grain samples- figure 1H). Subsequently, a sample of each board was obtained for each type of workability test. The tests performed were: planing, sanding, mortising, shaping, boring and turning, following the specifications in D1666-11 (ASTM 2011), with amendments proposed to test effects of tropical timber "Workability Standards of the Cartagena Agreement" (Acuerdo de Cartagena 1976). Planing consists in planing (brushing) the samples using two angles of blades $\left(15^{\circ}\right.$ and $\left.30^{\circ}\right)$ in two feet rate $\left(6\right.$ and $\left.30 \mathrm{~m} \mathrm{~min}^{-1}\right)$. In the standard sanding test, the aspects of temperature measurement and sawdust removal are not considered, though this was included using the criteria developed by Serrano (1983). Temperature was measured by a laser type temperature gauge (Raytec Brand, model Raynger ST) immediately after sanding. The removal in the sanding process was calculated using equation 1 . In the boring test, the chip thickness calculation was included (equation 2). This test basically uses drill bits used for wood and metal, both with two speeds. The classification for different workability performance is detailed in table 2 of the reference Moya et al (2015). More information about the classification of all tests can be found in Serrano (1983).

$$
\begin{gathered}
\text { Removal }=\frac{\text { Roughing }}{V_{\text {sandpaper }} * T^{*} N} \\
\mathrm{CT}=\frac{\text { Depthof hole in mm }}{\text { Drilling time in min * rpm } * \text { number of propellers }}
\end{gathered}
$$

\section{Where:}

Roughing $=\mathrm{mm}$ removed based on an average of $0.5 \mathrm{~mm}$, $\mathrm{V}_{\text {sandpaper }}=$ sanding speed $\mathrm{m} / \mathrm{min}, \mathrm{t}=$ duration of sanding, $\mathrm{N}$ $=$ number of passes to achieve a roughing of approximately $0.5 \mathrm{~mm}, \mathrm{CT}=$ chip thickness.

Statistical analyses. A general statistical description (average and coefficient of variation) was performed for all wood properties. An analysis of variance (ANOVA) was used to test differences among fast growth plantation species for physical, mechanical and chemical properties, extractives content, decay durability, preservation parameters and workability properties. Mean differences between species were evaluated using Tukey test $(P<0.01)$. Regression analyses were applied for the wood characteristics evaluated (heartwood, sapwood, and bark percentage) by tree height, where stem height was an independent factor and wood properties with dependent variable.

\section{RESULTS}

General and physical properties. H. alchorneoides showed the statistically lowest value of heartwood percentage and $S$. saman the highest. The highest value of pith percentage was in $H$. alchorneoides and C. alliodora; V. ferruginea and in $S$. saman the lowest. Bark percentage value was the lowest for $D$. panamensis and for C. alliodora it was the highest. Regarding physical properties (table 2), D. panamensis protrudes with the highest values of specific gravity and volumetric shrinking, but with the lowest initial moisture content (MCi). Whereas, C. alliodora and $V$. ferruginea showed intermediate values for specific gravity and $\mathrm{MCi}$, however with high green densities. Tangential/radial shrinking ratio for all species was lower than 2, and with no significant difference among species.

The study of general properties across showed that the percentage of heartwood decreases with increasing height of the tree, but DP decreased. While SS has the highest at the base of the tree (figure 2A). The percentage of bark in different species increases with the height of the tree (figure 2B). Besides, it was found that DP presented irregular 
Table 2. Different wood part characteristics and physical properties of six different fast-growth plantation species in Costa Rica ( $N=9$ ). Características de los árboles y propiedades de seis especies de rápido crecimiento de Costa Rica $(\mathrm{N}=9)$.

\begin{tabular}{lcccccc}
\hline Wood properties & $\begin{array}{c}\text { Cordia } \\
\text { alliodora }\end{array}$ & $\begin{array}{c}\text { Dipteryx } \\
\text { panamensis }\end{array}$ & $\begin{array}{c}\text { Enterolobium } \\
\text { cyclocarpum }\end{array}$ & $\begin{array}{c}\text { Hieronyma } \\
\text { alchorneoides }\end{array}$ & $\begin{array}{c}\text { Samanea } \\
\text { saman }\end{array}$ & $\begin{array}{c}\text { Vochysia } \\
\text { ferruginea }\end{array}$ \\
\hline Heartwood (\%) & $23.4^{\mathrm{bc}}(86.3)$ & $24.8^{\mathrm{bc}}(42.6)$ & $33.1^{\mathrm{ab}}(30.4)$ & $8.5^{\mathrm{c}}(58.1)$ & $48.4^{\mathrm{a}}(15.4)$ & $25.0^{\mathrm{bc}}(37.8)$ \\
Pith (\%) & $0.03^{\mathrm{c}}(68.7)$ & $0.24^{\mathrm{b}}(10.6)$ & $0.24^{\mathrm{b}}(19.7)$ & $0.33^{\mathrm{a}}(39.1)$ & $0.01^{\mathrm{c}}(46.2)$ & $0.03^{\mathrm{c}}(56.5)$ \\
Bark (\%) & $18.3^{\mathrm{a}}(31.1)$ & $8.9^{\mathrm{c}}(10.0)$ & $10.3^{\mathrm{bc}}(18.5)$ & $13.8^{\mathrm{b}}(18.3)$ & $9.8^{\mathrm{bc}}(27.6)$ & $11.0^{\mathrm{bc}}(23.2)$ \\
Specify gravity & $0.34^{\mathrm{c}}(14.3)$ & $0.63^{\mathrm{a}}(4.3)$ & $0.36^{\mathrm{c}}(16.0)$ & $0.49^{\mathrm{b}}(11.6)$ & $0.49^{\mathrm{b}}(7.2)$ & $0.35^{\mathrm{c}}(9.8)$ \\
Initial moisture content (\%) & $156^{\mathrm{b}}(20.3)$ & $59^{\mathrm{d}}(11.4)$ & $170^{\mathrm{ab}}(12.4)$ & $116^{\mathrm{c}}(13.7)$ & $106^{\mathrm{c}}(9.9)$ & $176^{\mathrm{a}}(8.0)$ \\
Green density $\left.(\mathrm{g} \mathrm{cm})^{-3}\right)$ & $0.85^{\mathrm{d}}(10.5)$ & $1.00^{\mathrm{bc}}(0.5)$ & $1.00^{\mathrm{bc}}(5.5)$ & $1.08^{\mathrm{a}}(3.9)$ & $1.02^{\mathrm{b}}(4.3)$ & $0.96^{\mathrm{c}}(5.7)$ \\
Radial shrinking $(\%)$ & $3.9^{\mathrm{abc}}(29.9)$ & $4.6^{\mathrm{ab}}(27.2)$ & $1.7^{\mathrm{d}}(27.6)$ & $3.6^{\mathrm{bc}}(20.4)$ & $2.7^{\mathrm{dd}}(25.0)$ & $5.5^{\mathrm{a}}(38.5)$ \\
Tangential shrinking $(\%)$ & $5.6^{\mathrm{a}}(15.6)$ & $5.3^{\mathrm{ab}}(15.1)$ & $2.6^{\mathrm{c}}(36.8)$ & $5.5^{\mathrm{ab}}(19.9)$ & $4.1^{\mathrm{b}}(25.9)$ & $6.0^{\mathrm{a}}(11.1)$ \\
Volumetric shrinking $(\%)$ & $9.6^{\mathrm{c}}(28.9)$ & $27.9^{\mathrm{a}}(8.5)$ & $5.0^{\mathrm{c}}(58.4)$ & $12.3^{\mathrm{b}}(8.7)$ & $9.2^{\mathrm{c}}(26.4)$ & $11.5^{\mathrm{bc}}(12.6)$ \\
Shrinking ratio & $1.6^{\mathrm{a}}(40.5)$ & $1.2^{\mathrm{a}}(25.8)$ & $1.7^{\mathrm{a}}(53.5)$ & $1.6^{\mathrm{a}}(23.8)$ & $1.6^{\mathrm{a}}(40.5)$ & $1.2^{\mathrm{a}}(32.5)$ \\
\hline
\end{tabular}

Note: Value in parenthesis represents the coefficient of variation; different letters in the same line are statistically different at $99 \%$.

variation among species; in HA it increases with height up $75 \%$, and in the other species, DP presented stable across trunk (figure 2C).

For the longitudinal variation of physical properties, the initial moisture content showed few variations in H. alchorneoides and S. saman, whereas for D. panamensis, the initial moisture content increased as tree height increases to $75 \%$ and then decreased. In C. alliodora and E. cyclocarpum, opposite results occurred. Initial moisture content increased until $25 \%$, afterward decreased until $75 \%$ of tree height, to finally increase again (E. cyclocarpum) and remain stable (C. alliodora). Vochysia ferruginea was the only species whose initial moisture content decreased with tree height (figure 2D). Variation of green density with tree height was observed in D. panamensis, $H$. alchorneoides and V. ferruginea. Cordia alliodora, S. saman and E. cyclocarpum presented density decrease with tree height. However, in E. cyclocarpum, unlike in the other species, density increased after $75 \%$ height. Finally, specific gravity remained stable with height in most species, except for $D$. panamensis, whose specific gravity decreased until $75 \%$ height to later increase.

Mechanical properties. As expected, statistical differences were found in the mechanical properties for all species. $D$. panamensis presented the highest values for most mechanical properties (except for perpendicular strength to fiber/radial). Cordia alliodora, E. cyclocarpum and $V$. ferruginea showed the lowest, whereas $H$. alchorneoides and $S$. saman presented intermediate values (table 3 ).

Chemical properties. The $\mathrm{pH}$ varied from 5.0 to 8.8. Cordia alliodora had a value superior to 8 , whereas the other species showed values inferior to 8 . Percentages of hemicellulose and lignin ranged from $14.5 \%$ to $32.0 \%$ and from $62.0 \%$ to $80.0 \%$, respectively; no differences appeared among species (table 4).

Regarding macronutrients, C. alliodora was the specie with the highest nitrogen, whereas $D$. panamensis had the lowest value. For carbon, there were differences only between $H$. alchorneoides and C. alliodora. Phosphorus content was despised for D. panamensis, H. alchorneoides and V. ferruginea. For the other species, percentage varied from $0.01 \%$ to $0.02 \%$. Calcium ranged from $0.08 \%$ to $0.34 \%$. Statistical differences were observed between $C$. alliodora and $H$. alchorneoides, D. panamensis and $V$. ferruginea. The species with the highest magnesium was $C$. alliodora, whereas $H$. alchorneoides and D. panamensis showed the lowest values. For potassium content, important differences appeared between E. cyclocarpum and S. saman, with the highest values, and D. panamensis and V. ferruginea, with the lowest. Percentage of sulfur varied from $0.01 \%$ to $0.04 \%$; E. cyclocarpum, S. saman and C. alliodora had the statistically highest values, whereas $D$. panamensis, $H$. alchorneoides and $V$. ferruginea the lowest values.

For the micronutrients content, iron ranged from $20 \mathrm{mg}$ $\mathrm{kg}^{-1}$ to $242 \mathrm{mg} \mathrm{kg}^{-1} ;$ D. panamensis, E. cyclocarpum and H. alchorneoides presented the statistically highest values and $S$. saman and V. ferruginea the lowest. For copper content, the range was $3.1 \mathrm{mg} \mathrm{kg}^{-1}$ to $21.8 \mathrm{mg} \mathrm{kg}^{-1} ; C$. alliodora and $V$. ferruginea presented the highest values, and E. cyclocarpum, D. panamensis, S. saman and H. alchorneoides the lowest ones. Zinc variation was from $3.0 \mathrm{mg}$ $\mathrm{kg}^{-1}$ to $15.5 \mathrm{mg} \mathrm{kg}^{-1}$; E. cyclocarpum obtained the highest value and $H$. alchorneoides the lowest one. In relation to manganese content, no statistical differences were found 

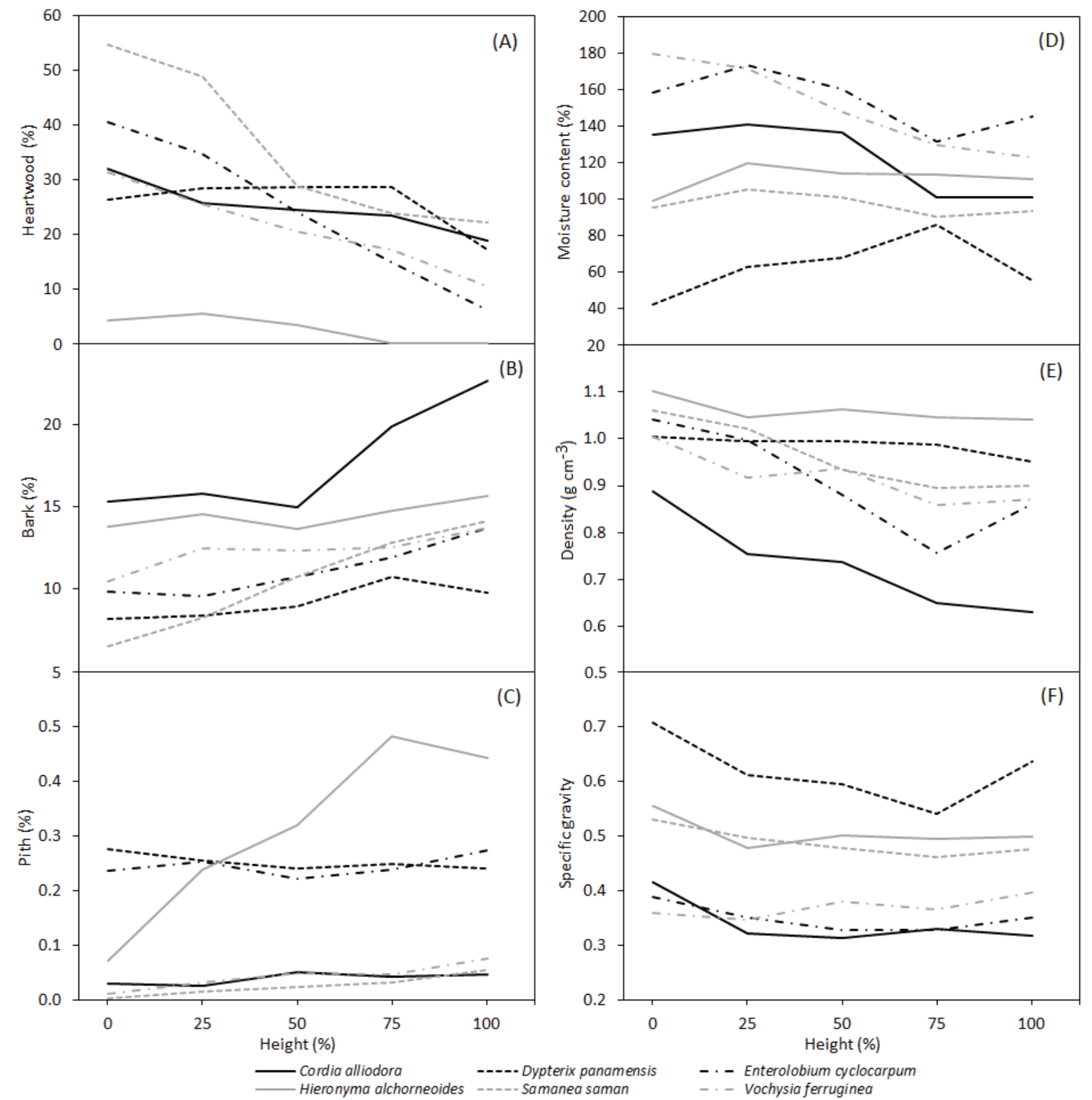

Figure 2. Variation of heartwood (A), bark (B) and pith percentage (C), initial moisture content (D), green density (E) and specify gravity $(\mathrm{F})$ with stem height in six different fast-growth plantation species in Costa Rica.

Variación del porcentaje de duramen (A), corteza (B) y médula (C), contenido de humedad verde (D), densidad verde (E) y densidad básica (F) con la altura en seis especies de rápido crecimiento de Costa Rica.

among most species, excepting $V$. ferruginea. Finally, $C$. alliodora was the species with the highest boron content, whereas H. alchorneoides had the lowest value (table 4).

Extractives. The analysis of extractives in cold water showed a variation from $10.4 \%$ to $24.3 \%$. Cordia alliodo$r a$ was the species with the statistically highest percentage, whereas $H$. alchorneoides the lowest one. In hot water, the extractive percentage ranged from $11.0 \%$ to $19.5 \%$; E. cyclocarpum, S. saman, V. ferruginea and H. alchorneoides showed the highest values (table 5). Extractive percentage in sodium hydroxide varied from $8.3 \%$ to $28.0 \%$. Vochysia ferruginea, S. saman and E. cyclocarpum had the highest extractive percentage, whereas $H$. alchorneoides and $C$. alliodora obtained the lowest percentages. Extractives in ethanol-toluene varied from $9.4 \%$ to $18.0 \% ; S$. $s a$ - 
Table 3. Average of wood mechanical properties of six different fast-growth plantation species at $12 \%$ moisture content $(\mathrm{N}=18)$. Valores promedio de propiedades mecánicas de seis especies de rápido crecimiento de Costa Rica al $12 \%(\mathrm{~N}=18)$.

\begin{tabular}{|c|c|c|c|c|c|c|c|}
\hline \multicolumn{2}{|c|}{$\begin{array}{l}\text { Mechanical } \\
\text { properties }\end{array}$} & $\begin{array}{c}\text { Cordia } \\
\text { alliodora }\end{array}$ & $\begin{array}{c}\text { Dipteryx } \\
\text { panamensis }\end{array}$ & $\begin{array}{l}\text { Enterolobium } \\
\text { cyclocarpum }\end{array}$ & $\begin{array}{c}\text { Hieronyma } \\
\text { alchorneoides }\end{array}$ & $\begin{array}{l}\text { Samanea } \\
\text { saman }\end{array}$ & $\begin{array}{c}\text { Vochysia } \\
\text { ferruginea }\end{array}$ \\
\hline \multirow{2}{*}{$\begin{array}{l}\text { Compression } \\
\text { strength } \\
(\mathrm{MPa})\end{array}$} & Parallel & $26.9^{\mathrm{c}}(20.7)$ & $55.9^{\mathrm{a}}(14.0)$ & $21.0^{\mathrm{c}}(16.5)$ & $42.7^{\mathrm{b}}(19.9)$ & $37.2^{\mathrm{b}}(11.5)$ & $24.0^{\mathrm{c}}(16.8)$ \\
\hline & Perpendicular & $11.5^{\mathrm{d}}(37.2)$ & $60.91^{\mathrm{a}}(17.5)$ & $21.3^{\mathrm{c}}(28.0)$ & $34.48^{\mathrm{b}}(21.6)$ & $38.0^{\mathrm{b}}(17.3)$ & $14.8^{\mathrm{cd}}(32.8)$ \\
\hline \multirow{2}{*}{$\begin{array}{l}\text { Tension strength } \\
\text { perpendicular to } \\
\text { fiber }(\mathrm{MPa})\end{array}$} & Tangential & $3.8^{\mathrm{b}}(23.5)$ & $6.8^{\mathrm{a}}(30.2)$ & $3.3^{b}(24.5)$ & $5.5^{\mathrm{a}}(29.1)$ & $5.7^{\mathrm{a}}(22.8)$ & $6.9^{\mathrm{a}}(18.1)$ \\
\hline & Radial & $4.1^{\mathrm{ab}}(18.3)$ & $3.4^{\mathrm{bc}}(39.9)$ & $2.8^{\mathrm{c}}(25.4)$ & $3.3^{\text {bc }}(43.9)$ & $4.5^{\mathrm{ab}}(31.5)$ & $5.1^{\mathrm{a}}(20.4)$ \\
\hline $\begin{array}{l}\text { Tension strength } \\
(\mathrm{MPa})\end{array}$ & Parallel & $48.3^{\mathrm{c}}(40.6)$ & $135.8^{\mathrm{a}}(27.3)$ & $35.8^{\mathrm{c}}(34.6)$ & $76.3^{\mathrm{b}}(24.8)$ & $86.8^{\mathrm{b}}(19.6)$ & $49.7^{\mathrm{c}}(26.2)$ \\
\hline \multirow{2}{*}{$\begin{array}{l}\text { Static bending } \\
\quad(\mathrm{MPa})\end{array}$} & MOE & $5180^{\mathrm{b}}(17.8)$ & $10324^{\mathrm{a}}(13.5)$ & $2921^{c}(23.6)$ & $\begin{array}{l}10424^{\mathrm{a}} \\
(17.4)\end{array}$ & $5122^{b}(16.7)$ & $5780^{\mathrm{b}}(13.1)$ \\
\hline & MOR & $72.0^{\mathrm{c}}(25.4)$ & $164.6^{\mathrm{a}}(12.7)$ & $30.7^{\mathrm{e}}(27.0)$ & $109.9^{b}(12.5)$ & $52.4^{\mathrm{d}}(14.0)$ & $75.2^{\mathrm{c}}(13.0)$ \\
\hline \multirow{2}{*}{$\begin{array}{l}\text { Shear strength } \\
\text { parallel to fiber } \\
(\mathrm{MPa})\end{array}$} & Tangential & $12.2^{\mathrm{c}}(11.3)$ & $17.6^{\mathrm{a}}(20.3)$ & $8.3^{c}(20.6)$ & $15.6^{\mathrm{b}}(10.3)$ & $15.6^{\mathrm{b}}(6.8)$ & $9.6^{\mathrm{c}}(17.8)$ \\
\hline & Radial & $8.7^{\mathrm{c}}(18.8)$ & $15.4^{\mathrm{a}}(19.3)$ & $6.8^{\mathrm{d}}(13.1)$ & $12.0^{\mathrm{b}}(13.7)$ & $13.9^{\mathrm{a}}(11.2)$ & $9.1^{\mathrm{c}}(14.7)$ \\
\hline \multirow{2}{*}{$\begin{array}{l}\text { Clivaje strength } \\
(\mathrm{MPa})\end{array}$} & Tangential & $0.6^{\mathrm{B}}(26.9)$ & $1.1^{\mathrm{a}}(36.6)$ & $0.5^{\mathrm{b}}(18.6)$ & $0.9^{\mathrm{a}}(24.2)$ & $0.7^{\mathrm{b}}(31.4)$ & ND \\
\hline & Radial & $0.6^{\mathrm{b}}(1.1)$ & $0.7^{\mathrm{a}}(26.1)$ & $0.4^{\mathrm{c}}(12.8)$ & $0.8^{\mathrm{a}}(1.2)$ & $0.6^{\mathrm{b}}(15.6)$ & ND \\
\hline \multirow{2}{*}{ Janka hardness (kg) } & Axial & $395^{\mathrm{c}}(16.6)$ & $1377^{\mathrm{a}}(26.6)$ & $448^{c}(13.8)$ & $700^{\mathrm{b}}(19.9)$ & $630^{\mathrm{b}}(17.4)$ & $420^{c}(13.3)$ \\
\hline & Lateral & $341^{\mathrm{c}}(17.6)$ & $1037^{\mathrm{a}}(20.6)$ & $327^{\mathrm{c}}(15.8)$ & $561^{\mathrm{b}}(24.0)$ & $588^{\mathrm{b}}(109.5)$ & $311^{\mathrm{c}}(40.1)$ \\
\hline \multirow{2}{*}{$\begin{array}{l}\text { Nail holding } \\
\text { strength }(\mathrm{kg})\end{array}$} & Axial & $48^{\mathrm{cd}}(13.1)$ & $165^{\mathrm{a}}(34.1)$ & $33^{\mathrm{d}}(25.8)$ & $92^{\mathrm{b}}(28.9)$ & $64^{c}(13.6)$ & $47^{\mathrm{cd}}(21.5)$ \\
\hline & Lateral & $63^{\mathrm{c}}(17.6)$ & $206^{\mathrm{a}}(25.2)$ & $44^{\mathrm{c}}(16.3)$ & $111^{\mathrm{b}}(29.5)$ & $91^{\mathrm{b}}(19.4)$ & $55^{\mathrm{c}}(18.1)$ \\
\hline
\end{tabular}

Legend: ND: not determined. Value in brackets is the coefficient of variation; different letters in the same line are statistically different at $99 \%$.

Table 4. Wood chemical composition of six different fast-growth plantation species in Costa Rica. Composición química de la madera de seis especies de rápido crecimiento de Costa Rica.

\begin{tabular}{|c|c|c|c|c|c|c|}
\hline Parameter & $\begin{array}{c}\text { Cordia } \\
\text { alliodora }\end{array}$ & $\begin{array}{c}\text { Dipteryx } \\
\text { panamensis }\end{array}$ & $\begin{array}{l}\text { Enterolobium } \\
\text { cyclocarpum }\end{array}$ & $\begin{array}{c}\text { Hieronyma } \\
\text { alchorneoides }\end{array}$ & $\begin{array}{l}\text { Samanea } \\
\text { saman }\end{array}$ & $\begin{array}{l}\text { Vochysia } \\
\text { ferruginea }\end{array}$ \\
\hline $\mathrm{pH}$ & $8.8^{\mathrm{a}}(5.8)$ & $5.0^{c}(3.9)$ & $5.2^{\mathrm{c}}(4.9)$ & $6.4^{\mathrm{b}}(13.7)$ & $5.2^{\mathrm{c}}(5.2)$ & $5.0^{\mathrm{c}}(0.7)$ \\
\hline Lignin (\%) & $27.1^{\mathrm{a}}(7.2)$ & $32.0^{\mathrm{a}}(1.3)$ & $26.7^{\mathrm{a}}(4.9)$ & $21.6^{\mathrm{a}}(21.2)$ & $19.0^{\mathrm{a}}(25.9)$ & $14.5^{\mathrm{a}(22.9)}$ \\
\hline Holocellulose (\%) & $68.5^{\mathrm{a}}(2.0)$ & $77.3^{\mathrm{a}}(1.0)$ & $80.0^{\mathrm{a}}(2.4)$ & $62.0^{\mathrm{a}}(2.3)$ & $79.0^{\mathrm{a}}(1.4)$ & $72.2^{\mathrm{a}}(0.3)$ \\
\hline Nitrogen (\%) & $0.54^{\mathrm{a}}(7.2)$ & $0.22^{\mathrm{c}}(14.9)$ & $0.33^{\mathrm{b}}(18.5)$ & $0.27^{\mathrm{bc}}(13.8)$ & $0.34^{\mathrm{b}}(10.0)$ & $0.27^{\mathrm{bc}}(8.7)$ \\
\hline Carbon (\%) & $47.1^{\mathrm{b}}(3.5)$ & $49.1^{\mathrm{ab}}(0.9)$ & $48.4^{\mathrm{ab}}(2.7)$ & $49.47^{\mathrm{a}}(75.0)$ & $48.0^{\mathrm{ab}}(2.3)$ & $49.3^{\mathrm{ab}}(4.2)$ \\
\hline Phosphorus (\%) & $0.02^{\mathrm{a}}(109)$ & ND & $0.0^{\mathrm{b}}(118)$ & ND & $0.01^{\mathrm{b}}(109)$ & ND \\
\hline Calcium (\%) & $0.34^{\mathrm{a}}(16.1)$ & $0.12^{b}(30.2)$ & $0.21^{\mathrm{ab}}(47.6)$ & $0.18^{\mathrm{b}}(45.6)$ & $0.23^{\mathrm{ab}}(48.9)$ & $0.08^{\mathrm{b}}(13.9)$ \\
\hline Magnesium (\%) & $0.10^{\mathrm{a}}(25.1)$ & $0.02^{\mathrm{b}}(31.0)$ & $0.06^{\mathrm{ab}}(91.0)$ & $0.04^{\mathrm{b}}(41.8)$ & $0.06^{\mathrm{ab}}(91.1)$ & $0.04^{\mathrm{ab}}(25.0)$ \\
\hline Potasium (\%) & $0.28^{\mathrm{b}}(23.7)$ & $0.07^{\mathrm{d}}(29.9)$ & $0.44^{\mathrm{a}}(16.5)$ & $0.18^{\mathrm{c}}(32.9)$ & $0.40^{\mathrm{a}}(6.9)$ & $0.07^{\mathrm{d}}(14.3)$ \\
\hline Sulfur $(\%)$ & $0.03^{\mathrm{ab}}(13.2)$ & $0.01^{\mathrm{b}}(0.0)$ & $0.04^{\mathrm{a}}(46.9)$ & $0.01^{\mathrm{b}}(37.2)$ & $0.03^{\mathrm{a}}(54.4)$ & $0.01^{\mathrm{b}}(0.0)$ \\
\hline Iron $\left(\mathrm{mg} \mathrm{kg}^{-1}\right)$ & $78^{\mathrm{bc}}(67.6)$ & $242^{\mathrm{a}}(34.5)$ & $206^{\mathrm{a}}(27.6)$ & $152^{\mathrm{ab}}(50.5)$ & $40^{c}(47.3)$ & $20^{c}(37.5)$ \\
\hline Copper $\left(\mathrm{mg} \mathrm{kg}^{-1}\right)$ & $21.8^{\mathrm{a}}(41.3)$ & $5.0^{\mathrm{b}}(25.3)$ & $5.7^{\mathrm{b}}(21.4)$ & $3.1^{b}(41.5)$ & $4.7^{\mathrm{b}}(87.5)$ & $15.0^{\mathrm{a}}(17.6)$ \\
\hline Zinc $\left(\mathrm{mg} \mathrm{kg}^{-1}\right)$ & $8.0^{\mathrm{b}}(21.8)$ & $6.5^{\mathrm{bc}}(44.3)$ & $15.5^{\mathrm{a}}(8.9)$ & $3.0^{c}(105.4)$ & $4.3^{\mathrm{bc}}(28.0)$ & $4.3^{\mathrm{bc}}(35.3)$ \\
\hline Manganese $\left(\mathrm{mg} \mathrm{kg}^{-1}\right)$ & $3.4^{\mathrm{b}}(13.5)$ & $10.3^{b}(14.6)$ & $4.3^{\mathrm{b}}(37.7)$ & $11.1^{\mathrm{b}}(54.9)$ & $4.5^{\mathrm{b}}(62.5)$ & $365.0^{\mathrm{a}}(17.8)$ \\
\hline Boron $\left(\mathrm{mg} \mathrm{kg}^{-1}\right)$ & $4.8^{\mathrm{a}}(7.5)$ & $2.5^{\mathrm{bc}}(21.9)$ & $4.2^{\mathrm{ab}}(23.6)$ & $1.3^{\mathrm{c}}(140.2)$ & $3.7^{\mathrm{ab}}(14.1)$ & - \\
\hline
\end{tabular}

Note: ND: not determined, those chemical elements were not measured in chemical analyses. Value in parenthesis is the coefficient of variation and different letters among species and same wood properties are statistically different at $99 \%$. 
man had the highest value and $H$. alchorneoides the lowest one. For the extractives in dichloromethane, a variation between $3.1 \%$ and $15.6 \%$ was found; V. ferruginea and C. alliodora had the highest values (table 5).

Wood preservation. For all species it was possible to observe the preservative penetration in sapwood, with a partial irregular penetration type, except for D. panamensis that also showed vascular penetration (figure 3 ). In heartwood, no preservative penetration was observed in C. alliodora, E. cyclocarpum, H. alchorneoides or S. saman. For D. panamensis and $V$. ferruginea samples, heartwood was not present; therefore, it was not possible to determine its susceptibility to pre- serve heartwood (figure 3). Preservative absorption ranged from $84 \mathrm{~L} \mathrm{~m}^{-3}$ to $361 \mathrm{~L} \mathrm{~m}^{-3}$, whereas retention varied from $0.8 \mathrm{~kg} \mathrm{~m}^{-3}$ to $3.3 \mathrm{~kg} \mathrm{~m}^{-3}$ for all species. Results for absorption and retention of preservative (table 6) allow us to group species according to their differences: (i) C. alliodora as the species with the highest value, followed by (ii) E. cyclocarpum, and finally (iii) $H$. alchorneoides, D. panamensis, $S$. saman and $V$. ferruginea with the lowest values.

Durability. For sapwood, H. alchorneoides and V. ferruginea showed the lowest mass loss with both fungi, whereas E. cyclocarpum and S. saman had the highest mass loss with T. versicolor (figures 4A and 4B). For heartwood,

Table 5. Extractives in different solvent for six different fast-growth plantation species in Costa Rica.

Extractivos en diferentes solventes para seis especies de rápido crecimiento de Costa Rica.

\begin{tabular}{lccccc}
\hline \multirow{2}{*}{ Species } & \multicolumn{5}{c}{ Extractives percentage (\%) } \\
\cline { 2 - 6 } & Cool water & Hot water & NaOH at $1 \%$ & Ethanol toluene & Dichloromethane \\
\hline Cordia alliodora & $24.3^{\mathrm{a}}(1.7)$ & $14.0^{\mathrm{bc}}(10.4)$ & $8.3^{\mathrm{c}}(37.9)$ & $12.7^{\mathrm{bc}}(14.6)$ & $15.3^{\mathrm{b}}(9.0)$ \\
Dipteryx panamensis & $12.1^{\mathrm{c}}(3.5)$ & $11.0^{\mathrm{c}}(4.7)$ & $20.2^{\mathrm{b}}(4.3)$ & $10.3^{\mathrm{bc}}(10.5)$ & $10.6^{\mathrm{b}}(5.1)$ \\
Enterolobium cyclocarpum & $16.5^{\mathrm{b}}(6.2)$ & $19.5^{\mathrm{a}}(11.5)$ & $25.2^{\mathrm{ab}}(19.2)$ & $14.3^{\mathrm{ab}}(31.6)$ & $3.1^{\mathrm{d}}(3.8)$ \\
Hieronyma alchorneoides & $10.4^{\mathrm{d}}(16.2)$ & $15.4^{\mathrm{ab}}(3.9)$ & $13.3^{\mathrm{c}}(5.2)$ & $9.4^{\mathrm{c}}(2.8)$ & $5.70^{\mathrm{c}}(3.96)$ \\
Samanea saman & $16.1^{\mathrm{b}}(9.5)$ & $19.4^{\mathrm{a}}(16.9)$ & $27.4^{\mathrm{a}}(17.3)$ & $18.0^{\mathrm{a}}(18.2)$ & $9.8^{\mathrm{b}}(4.2)$ \\
Vochysia ferruginea & $16.9^{\mathrm{b}}(2.7)$ & $17.9^{\mathrm{ab}}(2.1)$ & $28.0^{\mathrm{a}}(1.4)$ & $15.2^{\mathrm{ab}}(1.5)$ & $15.6^{\mathrm{a}}(1.0)$ \\
\hline
\end{tabular}

Note: Value in parenthesis is coefficient of variation and different letters among species and same wood properties are statistically different at $99 \%$.

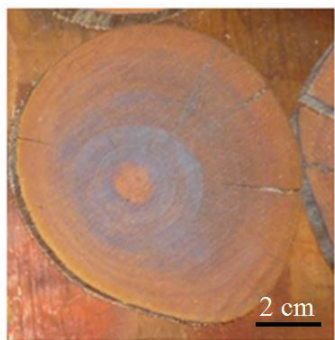

Cordia alliodora

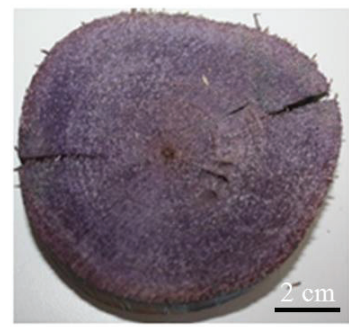

Hieronyma alchorneoides

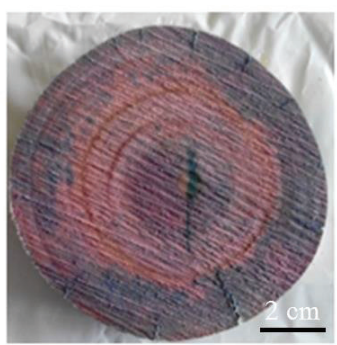

Dipteryx panamensis

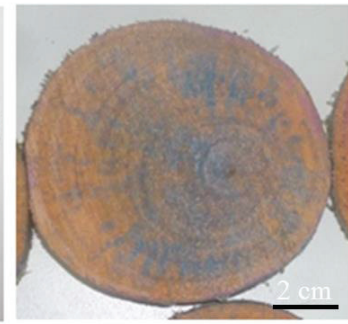

Samanea saman

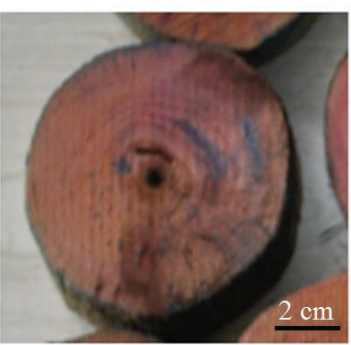

Enterolobium cyclocarpum

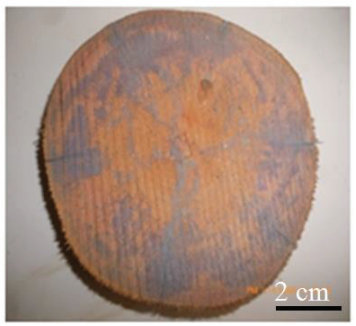

Vochysia ferruginea

Figure 3. Type of penetration in preserved wood with vacuum - pressure method in six different fast-growth plantation species in Costa Rica.

Tipos de penetración en madera preservada por el método vacío-presión en seis especies de rápido crecimiento en Costa Rica. 
Table 6. Penetration, absorption and retention capacity in wood preserved by vacuum-pressure methods for six different fast-growth plantation species in Costa Rica.

Penetración, absorción y capacidad de retención en madera preservada por el método vacío-presión en seis especies de rápido crecimiento de Costa Rica.

\begin{tabular}{|c|c|c|c|c|}
\hline \multirow{2}{*}{ Species } & \multicolumn{2}{|c|}{ Penetration } & \multicolumn{2}{|c|}{ Preservative uptake in sapwood } \\
\hline & Type & Possibility & Absorption $\left(\mathrm{L} \mathrm{m}^{-3}\right)$ & Retention* $\left(\mathrm{kg} \mathrm{m}^{-3}\right)$ \\
\hline Cordia alliodora & Partial irregular & No & $361^{\mathrm{a}}(23.6)$ & $3.3^{\mathrm{a}}(23.6)$ \\
\hline Dipteryx panamensis & Partial Irregular-Vascular & ND & $121^{\mathrm{c}}(89.2)$ & $1.1^{\mathrm{c}}(89.2)$ \\
\hline Enterolobium cyclocarpum & Partial irregular & No & $242^{\mathrm{b}}(52.9)$ & $2.2^{\mathrm{b}}(52.9)$ \\
\hline Hieronyma alchorneoides & Partial Irregular & No & $143^{\mathrm{c}}(38.5)$ & $1.3^{\mathrm{c}}(38.5)$ \\
\hline Samanea saman & Partial Irregular & No & $115^{\mathrm{c}}(64.6)$ & $1.0^{c}(64.5)$ \\
\hline Vochysia ferruginea & Partial Irregular & ND & $84^{\mathrm{c}}(61.0)$ & $0.8^{\mathrm{c}}(61.0)$ \\
\hline
\end{tabular}

Note: Value in parenthesis is the standard deviation; different letters among species and same wood properties are statistically different at $99 \%$. ND: preservation no determined because heartwood was not present. *Retention was calculated in a concentration of $2.8 \%$.
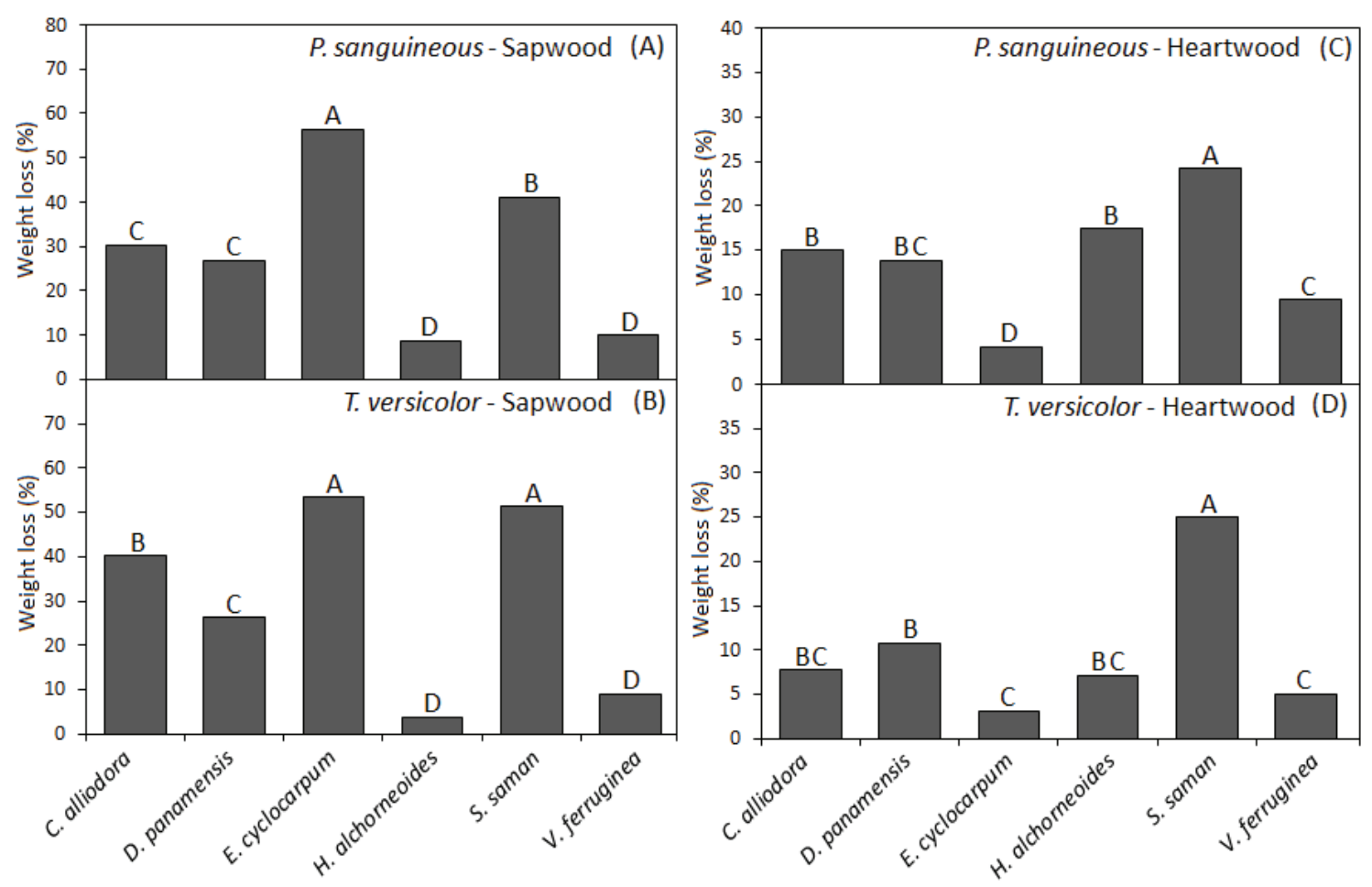

Figure 4. Percentage of weight loss in six different fast-growth plantation species in Costa Rica attacked by P. sanguineus (A) and T. versicolor (B) in sapwood and by P. sanguineus (C) and T. versicolor (D) in heartwood.

Pérdida de peso en madera de seis especies de rápido crecimiento en Costa Rica atacada por P. sanguineus (A) y T. versicolor (B) en la madera de albura y por P. sanguineus (C) and T. versicolor (D) en la madera de duramen.

with both fungi, S. saman had the highest mass loss whereas E. cyclocarpum and V. ferruginea showed the lowest (figures $4 \mathrm{C}$ and $4 \mathrm{D}$ ).

Workability. Planing was only possible to be performed in a $30^{\circ}$ angle with blades. Using these types of blades generated an excellent surface quality in C. alliodora, $H$. alchorneoides and $S$. saman with any speed; whereas in D. panamensis, E. cyclocarpum and V. ferruginea the quality of surface varied from very good to good (table 7).

For sanding test, the highest temperature was obtained in $H$. alchorneoides, followed by C. alliodora and 


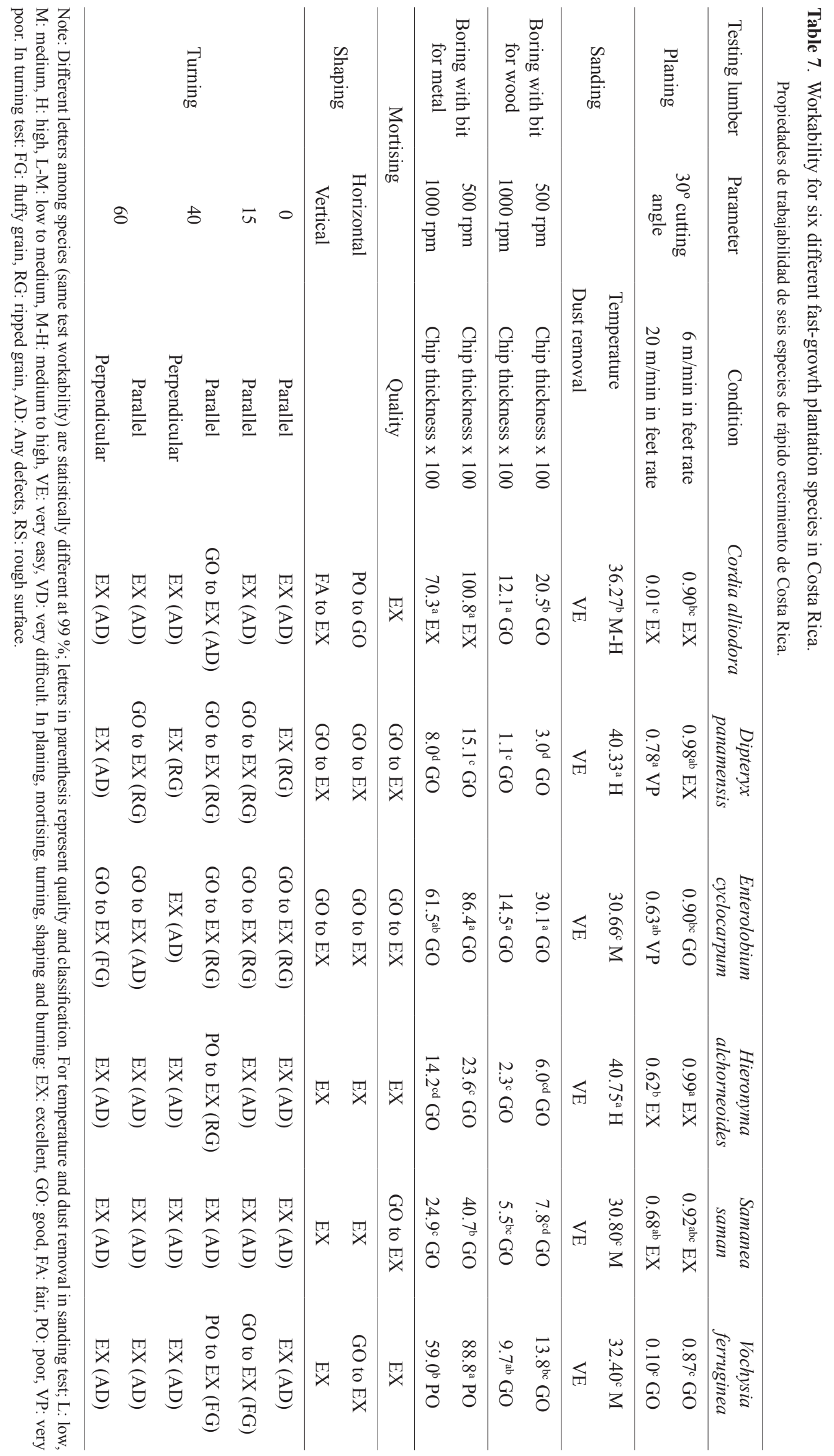


afterward the other species. Dust removal parameter indicates that all the species are classified as easy sanding (table 7). For boring bits for wood and metal, quality is good in C. alliodora, D. panamensis, E. cyclocarpum, H. alchorneoides and S. saman at speeds of 500 and 1,000 rpm, though with significant differences in chip thickness. For lumber of $V$. ferruginea, boring quality is good with wooden bit at any speed, but it is poor with metal bit at both speeds (table 7).

Performance of the species during the mortising and shaping testing showed that quality varies from good to excellent, except for $C$. alliodora for the latter test, where quality varies from poor to good in horizontal and from fair to excellent in vertical (table 7). For turning testing, qualities from good to excellent are presented on surfaces at different angles for almost all the species. Regarding turning defects, a ripped grain was found for D. panamensis, E. cyclocarpum and H. alchorneoides. Finally, a fluffy grain using $15^{\circ}$ and $40^{\circ}$ angles was found for $V$. ferruginea in parallel direction (table 7).

\section{DISCUSSION}

General, physical and mechanical properties. Heartwood percentages found in this study (8.5\% to $48.4 \%)$ are similar to those found by Moya and Muñoz (2010) on eight species from forest plantation in Costa Rica (7.2 \% to $69.7 \%$ ). Regarding bark percentage, that increased with tree height in all species (figure 2B), a similar performance was also observed by Moya and Muñoz (2010) for other plantation species.

It was observed that pith percentage of the different species had values inferior to $0.5 \%$ (table 2 ), which becomes an advantage at timber processing, increasing timber quality and quantity, since the recovery factor for timber decreases (Timell 1986). However, it was observed that tree height had no effect on pith percentage for most species, except for $H$. alchorneoides (figure 2C) and this same performance appeared in trees of $V$. guatemalensis and $A$. acuminata (Moya and Muñoz 2010).

The physical properties of the species influence their resistance and mechanical performance during industrial processes (Wiemann and Williamson 1989). Specific gravity is considered the property that best defines the mechanical performance of wood (Wiemann and Williamson 1989). Such behavior was verified in the current study: D. panamensis, the specie with the highest specific gravity (table 2), showed the highest values for mechanical resistance (table 3).

The initial moisture content is an important variable to the drying process. Moya and Muñoz (2010) noted that species with high initial moisture content are desirable due to their low drying time. Such behavior was proven by Tenorio et al. (2015) in a kiln drying study conducted over the same species. These authors found that species with high initial moisture content presented the lowest drying rates and the longest drying times.
Some studies indicate the species with low specific gravity tend to have radial and tangential shrinking (Moya and Munoz 2010); although, this study could not confirm this statement, since the values found were within the normal shrinking rate (table 2). Except for $V$. ferruginea, that had the highest radial and tangential shrinking values (table 2), but probably this performance is influenced by their short age, where trees produce shorter fiber (Wiemann and Williamson 1989).

Regarding mechanical properties, it was already indicated that $D$. panamensis had the highest values in most evaluated mechanical properties (table 3 ) as consequence of their high specific gravity (table 2). Likewise, the other species show a performance where low specific gravity decreases the mechanical properties of wood (Wiemann and Williamson 1989, Butterfield et al. 1993). Then according with mechanical and physical properties, the species with high density and mechanical properties ( $D$. panamensis and $H$. alchornoides) can be used for structural application, besides these species presented less workability properties. On the other hand, other species can be used for furniture application, because they presented moderate physical and mechanical properties and good workability properties.

Chemical properties and extractives. According to some studies, variations on the chemical content among species occur due to tree age, tree section, soil and climate type and type of conducted sampling (Bougnom et al. 2011). The variation among species studied showed this performance.

Wood has, generally, a slightly acidic pH (below 7) (Johns and Niazi 1980) this is fulfilled by most of the species in this study, except by $C$. alliodora. Very low $\mathrm{pH}$ leads to problems of corrosion of metals, or to a decrease in curing of the adhesive (Zelinka and Stone 2011). Meanwhile, C. alliodora wood showed a tendency to be basic (table 4), a situation that is not common in wood (Abe and Ono 1982). Regarding holocellulose and lignin content, again the difference among species is reflected. Moreover, within the hardwood species analyzed the variability that occurs in tropical woods is shown, which have a wide range of variation related to the amount of polysaccharides present in the cellulose and hemicellulose, amounts that are variables among species (Pereira et al. 2003). It was found that $D$. panamensis presented high lignin content, which is a disadvantage if it is utilized in pulp production, because high quantity of solvent must be used (Pereira et al. 2003).

The micro and macro elements in ash, although they do not have enormous importance from the perspective of wood use (Bougnom et al. 2011), are considered by some authors as important aspects related to ash production. This because they represent a waste necessary to handle and also because they are an indicator of the quantity of nutrients removed by the tree during growth. As expected, the amount of microelements varies among the different 
species (Bougnom et al. 2011), as occurred in this study (table 4). But the differences obtained should be taken with special care since these variations occur among species, tree age, tree section, soil type and climate, combustion type, type of sampling and wood storage. Importantly to point out the differences in the five micro-elements analyzed ( $\mathrm{Fe}, \mathrm{Cu}, \mathrm{Zn}, \mathrm{Mn}$ and $\mathrm{B}$ ) of $V$. ferruginea in relation to the other five species studied (table 4). This result agrees with studies by Kukachka and Miller (1980), who had noted the high concentration of microelements in the genre Vochysia, feature that can be used to identify the species of this genus.

The percentage of extractives (table 5) reflects the variation in the chemical composition of extractives found in the species, this because each solvent reflects the chemical nature of these compounds (Pereira et al. 2003). For example, the high values obtained in the extractives in hot and cold water reflect the amount of tannins, gums, sugars and coloring matters and starches (ASTM 2013b); hence, the highest values found in C. alliodora, E. cyclocarpum and $S$. saman indicate that these components are present in the wood. Likewise, high levels of soluble extractives in $\mathrm{NaOH}$, found in E. cyclocarpum, S. saman and V. ferruginea, indicate the high presence of low molecular weight extractives such as carbohydrates consisting mainly of hemicellulose and degraded cellulose in wood (ASTM 2013c). The high value of soluble extractives in dichloromethane, found in $V$. ferruginea, indicates the high presence of waxes, fats, resins, phytosterols and nonvolatile hydrocarbons in the wood of this species (ASTM 2013e). The high value of soluble extractives in dichloromethane, found in $C$. alliodora and $V$. ferruginea, indicates the high presence of waxes, fats, resins, phytosterols and nonvolatile hydrocarbons in the wood of this species (ASTM 2012e). Tropical wood extractives have several effects on the properties of wood, specifically by the values of swelling and shrinking, the equilibrium of moisture content that wood can reach, the dimensional stability and the physical and mechanical properties of wood (Kilic and Niemz 2012). Thereby, indicating that the differences found among species (table 5) affect the properties of the plantation species studied.

Preservation. The preservation of wood aims at increasing its resistance to insects and fungi attacks (Lloyd 1998). Regarding the preservation of wood through the vacuum pressure method, for all species, it is possible to preserve only sapwood - not heartwood - with a partial irregular type of penetration (table 6). The penetration type found in all the species analyzed occurs when the vessels have almost no obstructions to the passage of preservative lengthwise; though in the transverse direction there is important blockage of the vessels (Lloyd 1998).

The differences among anatomical structures of the species are determinant for the differences presented in the absorption and retention of the preservative (Keenan and
Tejada 1988). These authors found that the absorption of preservative is related to the wood density in different tropical species. However, this behavior was not fully complied by these plantation species (table 6). For example, C. alliodora, E. cyclocarpum and V.ferruginea, with similarly specific weight (table 2), showed large differences in absorption (table 6).

Durability. As expected, all species presented higher resistance in heartwood in relation to sapwood lumber (figure 4). Analyzing mass loss from the species, it was found that $H$. alchorneoides and $V$. ferruginea were more resistant to white rot fungi degradation (figure 4).

According to ASTM D-2017-81 standards (ASTM 2005), sapwood from E. cyclocarpum and S. saman is classified as not resistant to both white rot fungi types studied, which means that this wood type has low durability, since mass loss is superior to $45 \%$ (figure 4). Sapwood of $C$. alliodora and D. panamensis is found in the moderately resistant category as well as heartwood of S. saman. Whereas in $H$. alchorneoides and $V$. ferruginea sapwood is classified as resistant. Heartwood in most species is classified as from resistant to highly resistant, except for $S$. saman, which is moderately resistant.

Workability. Results obtained in the workability testing indicated that all species have good performance (table 7), except for planing with a $15^{\circ}$ angle blade, which was not executed. Likewise, previous properties differences among species were found. Studies by Serrano (1983) in Costa Rica and Torelli and Cufar (1996) with 43 Mexican woods from natural forest showed that species of low and high density (especially of interlocked grain) presented problems in different operations of workability; however, for this study, as for other tropical species of Costa Rica (Moya et al. 2015), it was not possible to confirm that.

\section{CONCLUSIONS}

Obtained results showed that heartwood percentage decreases with tree height. S. saman and E. cyclocarpum had the highest heartwood percentages, and also had a superior resistance to fungi attack. Bark percentage increases with tree height, whereas height has no effect on pith percentage; nevertheless, both percentages did not reach values that could affect the industrial process.

Dipteryx panamensis had the highest specific gravity values, as well as the highest values in mechanic resistance. For the other species, the lower the specific gravity, the lower the mechanic resistance in wood. Both chemical properties and extractives presence showed differences among the species, it was not possible to observe if any of the species had a higher concentration of chemical elements or extractives.

It was not possible to perform the preservation process in heartwood for any species, but it was possible for 
sapwood, where a partial irregular or vascular penetration occurred. The highest durability was for $H$. alchorneoides and $V$. ferruginea, species classified as possessing high durability. Finally, all species obtained good performance in the workability tests. The previous results indicate that species used for commercial reforestation in Costa Rica have acceptable characteristics to be used in commercialization and wooden products.

\section{ACKNOWLEDGEMENT}

The authors wish to thank the Vicerrectoría de Investigación y Extensión at the Instituto Tecnológico de Costa Rica, and Estación Horizontes-Guanacaste, CATIE, Reforest The Tropics Inc. that provided the material for this investigation.

\section{REFERENCES}

Abe I, Ono K. 1982. The acidity of wood and the extractives of some tropical species. Journal of the Japan Wood Research Society 28: 535-540.

Acuerdo de Cartagena, 1976. Normas y metodología para las actividades tecnológicas. Proyecto Andinos de Desarrollo Tecnológico en el área de recurso tropicales. Lima, Perú. Documento PADT. RFT/di. 225 p.

ASTM (American Society for Testing and Materials, US). 2014a. Standard test method for density and specific gravity (relative density) of wood and wood based materials. ASTM D2395-14. 8 p.

ASTM (American Society for Testing and Materials, US). $2014 \mathrm{~b}$. Standard test method for small clear specimens of timber. ASTM D143-14. 8.p.

ASTM (American Society for Testing and Materials, US). $2013 \mathrm{a}$. Standard test method for ash in wood. ASTM D1102-84 p.6.

ASTM (American Society for Testing and Materials, US). $2013 \mathrm{~b}$. Standard test methods for water solubility of wood. ASTM D1110-84. 8 p.

ASTM (American Society for Testing and Materials, US). 2013c. Standard test method for $1 \%$ sodium hydroxide solubility of wood. ASTM D 1109-84. 7 p.

ASTM (American Society for Testing and Materials, US). $2013 \mathrm{~d}$. Standard test method for ethanol-toluene solubility of wood.ASTM D1107-96. 6 p.

ASTM (American Society for Testing and Materials, US). 2013e. Standard test method for dichloromethane soluble in wood. ASTM D1108-96. 8p

ASTM (American Society for Testing and Materials, US). 2005. Standard Test Method of accelerated laboratory test of natural decay resistance of woods. ASTM D2017-81. 8 p.

ASTM (American Society for Testing and Materials, US). 2011. Standard test methods for conducting machining tests of wood and wood-base materials. ASTM D1666-11. 23 p.

Bougnom BP, BA Knapp, F Etoa, H Insam. 2011. Possible use of wood ash and compost for improving acid tropical soils. In Insam $\mathrm{H}$ and BA Knapp eds. Recycling of biomass ashes. New York, USA. Springer Verlag. p. 87-105.

Butterfield R, R Crook, R Adams, R Morris. 1993. Radial variation in wood specific gravity, fiber length and vessel area for two Central American hardwoods; Hyeronima alchor- neoides and Vochysia guatemalensis: natural and plantation-grown trees. IAWA Journal 17: 5-14.

Erickson HD. 1962. Some aspects of method in determining cellulose in wood. Tappi Journal 45:710-719.

Keenan FJ, M Tejada. 1988. Maderas tropicales como material de construcción en los países del grupo andino de América del Sur. Ottawa, Canada. Centro Internacional de Investigaciones para el Desarrollo. $147 \mathrm{p}$.

Kilic A, Niemz P. 2012. Extractives in some tropical woods. European Journal of Wood Products 70:79-83

Kukachka BF, RB Miller. 1980. Chemical spot-test for aluminum and its value in wood identification. IAWA Bulletin n.s. I: 104-109.

Lloyd JD. 1998. Borates and their biological applications. Stockholm Sweden. Inteernational Research Group on Wood Preservation, IRG/WP 98-30178, IRG Secretariat. 17 p.

Montagnini F. 2000. Accumulation in aboveground biomass and soil storage of mineral nutrients in pure and mixed plantations in a humid tropical lowland. Forests Ecology and Management 134: 257-270.

Moya R, L Leandro, O Murillo. 2009. Wood characteristics of Terminalia amazonia, Vochysia guatemalensis and Hyeronima alchorneoides planted in Costa Rica. Bosque 30(2): 78-87.

Moya R, F Muñoz. 2010. Physical and mechanical properties of eight fast-growing plantation species in Costa Rica. Journal of Tropical Forest Science 22(3): 317-328.

Moya R, C Salas, A Berrocal, JC Valverde. 2015. Evaluation of chemical compositions, air-dry, preservation and workability of eight fast-growing plantation species in Costa Rica. Maderas y Bosques 21( $\mathrm{N}^{\circ}$ especial): 31-47.

Moya R, C Tenorio C. 2013. Fuelwood characteristics and its relation with extractives and chemical properties of ten fastgrowth species in Costa Rica. Biomass and Bioenergy 56: 14-21.

Moya R, E Ureña, C Salas, F Muñoz, O Espinosa. 2013. Kiln drying behavior of lumber from ten fast-growth plantation species in Costa Rica. Wood Material Science and Engineering $8(1)$ : 37-45.

Nichols JD, JK Vanclay. 2012. Domestication of native tree species for timber plantations: key insights for tropical island nations. International Forestry Review 14: 402-413.

Obando MF, R Moya. 2013. Silviculture conditions and wood properties of Samanea saman and Enterolobium cyclocarpum in 19 year old mixed plantations. Forest Systems 22(1): 58-70.

Pereira H, J Graca, JC Rodriguez. 2003. Wood chemistry in relation to quality. In J Barnett G, J Eronimidis eds. Wood quality and its biological basis. London, UK. Blackwell Publishing. p. 3-40.

Serrano R. 1983. Características de cepillado, taladrado, lijado y torneado de 16 especies. III Parte. In Centro de Investigación en Ingeniería en Maderas ed. San José Costa Rica. Instituto Tecnológico de Costa Rica. Informe Final del proyecto: Propiedades físicas, mecánicas, preservación, durabilidad, cepillado, taladrado, lijado, torneado de 18 especies maderables de Costa Rica. 72 p.

Sparks DL ed. 1996. Methods of soil analysis. Part 3 - Chemical methods. Madison, WI, USA. SSSA and ASA. p. 205-230. SSSA Book Series No. 5.

TAPPI (Technical Association of the Pulp and Paper Industry, US). 2002. Standard test for acid-insoluble lignin in wood 
and pulp. Tappi T 222 om-02 revised 2002. 4 p.

Tenorio C, R Moya. 2013. Thermogravimetric characteristics, its relation with extractives and chemical properties and combustion characteristics of ten fast-growth species in Costa Rica. Thermochimica Acta 563: 12-21.

Tenorio C, R Moya. 2011. Kiln drying of Acacia mangium Will Wood: considerations of moisture content before and after drying and presence of wet pockets. Drying Technology 29: 1845-1854.

Tenorio C, C Salas, R Moya. 2015. Kiln drying behavior utilizing drying rate of lumber from six fast-growth plantation species in Costa Rica. Drying Technology DOI:10.1080/07373
937.2015 .1060493

Timell TE. 1986. Compresion Wood in Gymnospermes. Springer Verlag, Berlin. 705 p.

Torelli N, K. Čufar. 1996. Mexican tropical hardwoods: machinability, nailing and screwing. Holz als Roh-und Werkstoff 54: 69-71.

Wiemann M, G Williamson. 1989. Wood specific gravity gradients in tropical dry and montane rain forest trees. American Journal of Botany 76(6): 924-928.

Zelinka SL, Stone DS. 2011. The effect of tannins and $\mathrm{pH}$ on the corrosion of steel in wood extracts. Materials and Corrosion 62: 739-744.

Recibido: 11.05.15

Aceptado: 28.10.15 